\title{
A ação do tempo no paisagismo em Inhotim
}

\author{
LUIZ CARLOS ORSINI ${ }^{(1)}$
}

\begin{abstract}
RESUMO
Em Brumadinho/MG a natureza encontra a arte no Parque Ambiental de Inhotim, num projeto ousado de grande valor para a arte, paisagismo e para arquitetura. Aqui se respira cultura e ar puro. A vegetação e o acervo paisagístico têm na sua totalidade espécies tropicais do Brasil e de outras regiões tropicais pelo mundo. Na gestão $(2000$ - 2004) eram 30 hectares e hoje são 45 hectares de paisagens, com cinco lagos totalizando 3,5 hectares de lamina d'água. Toda essa água aliada a exuberância do paisagismo e a vegetação do entorno, influem diretamente num micro clima diferenciado, aumentando consideravelmente a umidade e o frescor no parque. É um autentico jardim paisagista, cheio de surpresas, descontinuidades através dos caminhos sinuosos, grupos botânicos magníficos, espécies vegetais inusitadas, recantos, praças, tudo isso em simbiose com a natureza, com a arquitetura dos pavilhões e as obras de arte que pousaram no paisagismo. Tudo isso tornam-se inevitáveis as surpresas dos percursos. Nesses quatro anos interruptos da execução das obras de infra-estrutura e paisagismo, Luiz Carlos Orsini chegou a trabalhar na implantação dos jardins com mais de 60 pessoas, entre jardineiros, ajudantes, tratoristas, operadores de guindaste e carreteiros. Havia dias que chegavam quatro carretas com palmeiras, dois guindastes, uma pá carregadeira e uma retro escavadeira dando apoio, as vezes era uma verdadeira operação de guerra. Foi um período de um aprendizado diferenciado, onde teve que assimilar a verdadeira escala do paisagismo, saber as dimensões das massas e volumes das plantas e como agrupa-las e harmonizá-las, recriando uma nova paisagem. Executando os lagos que foram projetados, o resto foi tudo sendo feito de improviso, impulsionado pela vontade em criar sempre situações distintas daquelas já executadas. Os artistas plásticos tiveram liberdade de interagir com o jardim e, muitas vezes escolher o local para dispor suas obras. Inhotim é um lugar especial, com a particularidade de ser um Parque Ambiental Museu. O Inhotim já virou roteiro para críticos, diretores e curadores de museus nacionais e internacionais e já é considerado um dos melhores do mundo na sua categoria. Ali a relação Arte x Espaço é participe singular de uma experiência única que temos certeza, o tempo irá consagrar. Vale a pena conferir!
\end{abstract}

Palavras-chave: paisagem, jardins, plantas ornamentais, parque, arte

\section{ABSTRACT \\ The time influence on Inhotim landscape}

Art meets nature at the Inhotim Environmental Park, located in Brumadinho Minas Gerais / MG. It is widely regarded a bold project of great value to art, landscaping and architecture. Inhotim is the place where is possible to breathe both fresh air and the culture. The natural vegetation and the landscaped collection assemble a wide range of tropical species from Brazil and from other tropical regions of world. From (2000 - 2004) the park consisted of 30 hectares, but just now grown to 45 exquisite hectares of countryside, with five lakes comprising 3.5 hectares of laminar water. The water combined with the exuberant landscaping and the surrounding plants, create a distinct microclimate, considerably increasing the moisture and freshness of the park. The landscaped garden is full of surprises through the winding paths and magnificent botanical groups, unusual plant species, places and squares are in harmony with nature, architecture and with the art. All this creates unique surprises along the numerous pathways. In these four years of uninterrupted infrastructure and landscaping work, Luiz Carlos Orsini, also contributed to the implementation of gardens working with more than 60 people, including gardeners, helpers, tractor, crane operators and carriers. Some days the extensive work counted fours trucks totally filled with palm trees, two cranes, a loader and a backhoe excavator supporting, making of this a real hard work. It was a period of a differentiated learning and Orsini had to assimilate the true scale of the landscaping, to know the dimensions of the masses and volumes of plants and groups and how to harmonize them, recreating them, recreating a new landscape. Beside the execution of the lake project design, all the rest was being done suddenly, driven by the desire to create situations where other than those already implemented. The plastic artists were free to interact with the garden and to choose where to exhibit their works. Inhotim is really a special place, with the particularity of being an Environmental Park Museum. It has become a roadmap for the critics, directors and national and international museums curators. The park is considered one of the world's best in its category. The relationship between Art and Space makes this place singular, turning it into a unique experience that certainly will be consecrated by the time. It's worth visiting!

Keywords: landscape, gardens, ornamentals plants, park, art.

\footnotetext{
(1) Paisagista, São Paulo - SP. paisagismo@lcorsini.com.br, www.lcorsini.com.br.
} 


\section{A AÇÃO DO TEMPO NO PAISAGISMO EM INHOTIM}

Em Brumadinho/ MG a natureza encontra a arte no Parque Ambiental de Inhotim, num projeto ousado de grande valor para a arte, paisagismo e para arquitetura. Aqui se respira cultura e ar puro.

A paisagem do entorno esconde mais de 3 milhões de $\mathrm{m}^{2}$ de mata nativa com fragmentos de mata atlântica e cerrado e dentro dessa área ambiental descortina-se em meio à sua exuberância tropical o parque de Inhotim.

Nos anos 80 Bernardo Paz, idealizador do Inhotim, chamou Roberto Burle Marx para visitar seu sítio e chegou a dar algumas opiniões sob o paisagismo. Em meados dos anos 80 foi Pedro Nehring quem executou o paisagismo do sitio totalizando $30.000 \mathrm{~m}^{2}$. A partir de 1993, Luiz Carlos Orsini, começou a trabalhar para Bernardo Paz, onde vinha mantendo e adequando os jardins remanescentes. Em Setembro de 2000, iniciaram-se as obras do Inhotim, e, Luiz Carlos Orsini juntamente com Bernardo Paz foram traçando, recriando a natureza, aumentando em $270.000 \mathrm{~m}^{2}$ o paisagismo no antigo sítio, onde está o parque. O paisagismo da primeira etapa finalizou em Setembro/ 2004, coincidindo com a inauguração oficial do parque.

Algumas coleções botânicas foram consolidadas e tem um papel relevante no acervo paisagístico e botânico do parque. As coleções botânicas são singulares, sendo as de maiores destaques as de Beucarmea recurvata (nolina ou pata-deelefante), Cycadaceae zamiaceae, e palmae (jerivás, butiás, tamareiras, macaúbas, buritirana, phoenix, corypha, entre muitas outras).

Compondo ainda com essas grandes coleções botânicas, são cultivadas nos jardins de Inhotim espécies de intensa floração e frutificação com destaques para as famílias: Musaceae, Araceae, Melostamataceae, Leguminosae, Orquidaceae, Bromeliaceae, Liliaceae, Lythraceae, Palmae, Moraceae, Acanthaceae, Myrtaceae, Zinziberaceae, Verbenaceae, Imdaceae, Melastonaceae, Fabaceae, Dicksoniaceae, Bignoviaceae, entre outras.

A vegetação e o acervo paisagístico têm na sua totalidade espécies tropicais do Brasil e de outras regiões tropicais pelo mundo. Na gestão $(2000$ - 2004) eram 30 hectares e hoje são 45 hectares de paisagens, com cinco lagos totalizando 3,5 hectares de lamina d'água. Toda essa água aliada a exuberância do paisagismo e a vegetação do entorno, influem diretamente num micro clima diferenciado, aumentando consideravelmente a umidade e o frescor no parque.

O compromisso com o meio ambiente, com base na Gestão Ambiental eficiente, é uma das bandeiras de Inhotim. Isso reduz o impacto ambiental e faz de Inhotim um local totalmente auto-sustentável, no que se diz respeito ao uso dos recursos naturais. Essa gestão eficiente permite o cultivo em
Inhotim de uma grande diversidade de espécies da flora (cerca de 2.100) nos dias de hoje.

É um autentico jardim paisagista, cheio de surpresas, descontinuidades através dos caminhos sinuosos, grupos botânicos magníficos, espécies vegetais inusitadas, recantos, praças, tudo isso em simbiose com a natureza, com a arquitetura dos pavilhões e as obras de arte que pousaram no paisagismo. Tudo isso torna-se inevitáveis as surpresas dos percursos.

Nesses quatro anos interruptos da execução das obras de infra-estrutura e paisagismo, Luiz Carlos Orsini chegou a trabalhar na implantação dos jardins com mais de 60 pessoas, entre jardineiros, ajudantes, tratoristas, operadores de guindaste e carreteiros.

Havia dias que chegavam quatro carretas com palmeiras, dois guindastes, uma pá carregadeira e uma retro escavadeira dando apoio, as vezes era uma verdadeira operação de guerra.

Os maciços, os traçados, os recantos, as formas vinham fluindo naturalmente como se o projeto já existisse pronto na minha imaginação. A inspiração e a forma de como executá-la, as vezes me trazia algum sofrimento, naturalmente... Que logo se pulverizava com o retorno do resultado obtido; diz Orsini.

Foi um período de um aprendizado diferenciado, onde teve que assimilar a verdadeira escala do paisagismo, saber as dimensões das massas e volumes das plantas e como agrupa-las e harmonizá-las, recriando uma nova paisagem. Executando os lagos que foram projetados, o resto foi tudo sendo feito de improviso, impulsionado pela vontade em criar sempre situações distintas daquelas já executadas.

Esta grande diversidade ajudou a equilibrar o ambiente restaurando a harmonia natural, atraindo a fauna autoctonia, como é informado. A catalogação de 136 espécies de aves, além de ser um local de sobrevivência, alimentação é também local de reprodução das mais variadas formas de vida.

Luiz Carlos Orsini e Bernardo Paz conseguiram criar um cenário arrebatador com um pujante paisagismo tropical. $\mathrm{O}$ Inhotim hoje conta com dez galerias, sendo oito projetadas pelo Arquiteto mineiro Paulo Orsini, além do Pavilhão da Portaria que teve o cuidado em ativar a relação entre a arquitetura e natureza, e outros 02 novos que foram construídos após 2004, um projetado pelo Arquiteto Rodrigo Cerviño Lopes e outro projetado pela dupla de Arquitetos Carlos Granada e Paula Zasnicoff.

Os Artistas Plásticos tiveram liberdade de interagir com o jardim e, muitas vezes escolher o local para dispor suas obras.

Inhotim é um lugar especial, com a particularidade de ser um Parque Ambiental Museu. O Inhotim já virou roteiro para críticos, diretores e curadores de museus nacionais e internacionais e já é considerado um dos melhores do mundo na sua categoria.

Ali a relação Arte x Espaço é participe singular de uma experiência única que temos certeza, o tempo irá consagrar. Vale a pena conferir! 